\title{
SENIOR LEADERSHIP: AN ANNOTATED BIBLIOGRAPHY OF THE MILITARY AND NONMILITARY LITERATURE
}

Melvin J. Kimmel

Submitted by:

T. Owen Jacobs, Chief

LEADERSHIP AND MANAGEMENT TECHNICAL AREA

Approved by:

Cecil D. Johnson, Director

MANPOWER AND PERSONNEL

RESEARCH LABORATORY

U.S. ARMY RESEARCH INSTITUTE FOR THE BEHAVIORAL AND SOCIAL SCIENCES 5001 Eisenhower Avenue, Alexandria, Virginia 22333

Office, Deputy Chief of Staff for Personnel

Department of the Army

June 1981 